\title{
ROSS RIVER VIRUS IS A MOSQUITO-TRANSMITTED ALPHAVIRUS: IS IT THREATENED TO ARAB COUNTRIES INCLUDING EGYPT?
}

\author{
By
}

\author{
NAGWA ZEIN EL ABDEEN ALY ${ }^{1}$, NAHLA M. SHOUKRY ${ }^{2}$ \\ AND TOSSON A. MORSY ${ }^{3}$
}

Military Medical Academy, Cairo11291 ${ }^{1}$, Faculty of Science, Suez University ${ }^{2}$, and

Faculty of Medicine, Ain-Shams University, Cairo $11566^{3}$, Egypt

\section{Abstract}

Ross River virus (RRV) is mosquito-borne arboviral infection that causes fever, polyarthritis, and rash. First described in northern Australia and then, widely throughout Australia and many western South Pacific islands. It is common in the tropical coastal regions of northern Australia. RRV can be transmitted by, Aedes aegypti, Ae. camptorhynchus, Ae. vigilax, and Culex annulirostris. Kangaroos, wallabies and horses are principal vertebrate hosts. Symptoms frequently occur together but may occur in single. Arthritis in wrists, knees, ankles, and finger joints is common and frequently symmetric. Rash is usually maculopapular involving limbs and trunk. Arthralgia may persist for up to 3 months. Fatigue is the commonest symptom. Diagnosis is by hemagglutination inhibition (HI) antibody and ELISA. A fourfold rise in HI titer is diagnostic; $\geq 1: 1280$ levels is recent infection. RRV-specific IgM persists for months after acute infection.

Treatment is supportive care, analgesics, and non-steroidal anti-inflammatory drugs. Feasible preventive measure is avoidance of mosquito bites. Helpful interventions include use of window and door screens, mosquito repellants, and light colored clothing. Over the long-term, drainage of mosquito breeding areas in endemic areas may be helpful to control infection.

\section{Introduction}

Ross River virus (RRV) is an arbovirus group transmitted by mosquitoes that causes a fev-erish disease manifest by polyarthritis and rash. The illness was first described in northern Australia in 1928 and subsequently has been observed widely through Australia and many islands of the western South $\mathrm{Pa}$ cific. It is most the most prevalent vector borne disease in Australia. The virus can be transmitted by many mosquito species and survives in mosquito eggs in arid environments (Kelly-Hope et al, 2004). Therefore, it has capacity to spread to other geographic areas worldwide (Toivanen, A, 2008).

Epidemiology: RRV infection was described in mainland Australia, Papua New Guinea (Fraser et al, 1988), the Solomon Islands, the islands of eastern Indonesia, and western South Pacific (Fauran et al, 1984), Fiji (Rosen et al, 1981), and American Samoa (Tesh et al, 1981). As many as 500,000 people were infected in Fiji when the disease first appeared in 1979 (Aaskov et al, 1981). Outbreaks have been described in American Samoa, New Caledonia, French Polynesia, the Cook Islands, and most states of Austral-

\section{lia (Lindsay et al, 1996).}

In Australia, about 6000 people were infected annually (Bi et al, 2009). The highest infection rates were in the Northern Territory (Quinn et al, 2005). Endemic foci occur in more temperate eastern Australia. Infection was seen in outskirts of Sydney since 1997 (Amin et al, 1998). Epidemics increased in frequency, size, via Australia European settlements (Weinstein et al, 2011), expanded in Queensland (Tong et al, 2004) and South Australia (Selden and Cameron, 1996).

RRV occurs most frequently in tropical coastal regions with salt marsh habitats suitable for the principal mosquito vector species (Mackenzie and Smith, 1996). Infection is commonest in spring, after summer rains, or after salt marshes inundation by rain or tides. Virus persists in arid areas of inland Australia within desiccation-resistant mosquito eggs. Outbreaks occur after rain, when mosquitoes hatch (Lindsay et al, 1993),

Climate influences: Predicting disease activity differed among regions; relationships between climate, social, and environmental factors are complex. In the River Murray Valley in Southern Australia, important fact- 
ors include river height, rainfall, and mosquito abundance (Williams et al, 2009). In a Tasmanian study, a combination of high spring tides and excessive summer rainfall produced a salt marsh habitat with a high density of mosquitoes (Robertson et al, 2004). Isolation of RRV from these mosquitoes coincided with the onset of the first human cases of RRV infection. In Western Australia, climate data were moderately sensitive in predicting epidemics of $64 \%$; the addition of mosquito surveillance data improved sensitivity of an early warning model for epidemics of 90\% (Woodruff et al, 2006).

Dry-land salinity, a substantial and expanding problem in the wheat belt of Southwestern Australia, is associated with an abundance of Aedes camptorhynchus and increased potential for zoonotic transmission (Carver et al, 2009), although increased human seroprevalence was not yet been demonstrated (Jardine et al, 2008). Important factors for infection in the Darwin region of tropical Northern Australia include rainfall, minimum temperature, and abundance of 3 mosquito species (Jacups et al, 2008). The relative importance of these environmental factors differs according to region, but rainfall was associated with increased disease activity (Suhrbier and La Linn, 2004).

Who is at risk?: People who are in contact with known mosquito habitats and who live in warm, humid climates near bodies of water are at risk of infection. Ross River virus infections are the most common mosquitoborne infection in Australia and infections occurs in many rural areas in NSW. Infections are uncommon in the major cities and towns. Outbreaks can occur when local conditions of rainfall, tides and temperature promote mosquito breeding.

Vectors and hosts: Mosquito species that serve as vectors for RRV vary by region. In Australian coast Aedes vigilax (salt marsh mosquito) and Ae. camptorhynchus were major vectors; both are day feeding species. Except Tasmania in inland areas, a night feeding $C x$. annulirostris predominates (Wols- tenholme, 1992). Other vectors include $A e$ des aegypti, Ae. tremulus, Ae. polynesiensis, and many others (Harley et al, 2000), with the Ae. aegypti has the potentiality of RRV extend distribution.

Native macropods (kangaroos and wallabies) are the principal vertebrate hosts (Mylonas et al, 2002), infection occurs among other wild animals and livestock. In urban areas possums and horses are potential reservoirs (Kay et al, 2007). Vertical transmission occurs in mosquitoes, and man-mosquito-man transmission may occur. RRV in northwest Victoria showed that density of short-lived, highly fecund hosts, as domestic mice also influence rural disease transmission (Carver et al, 2008).

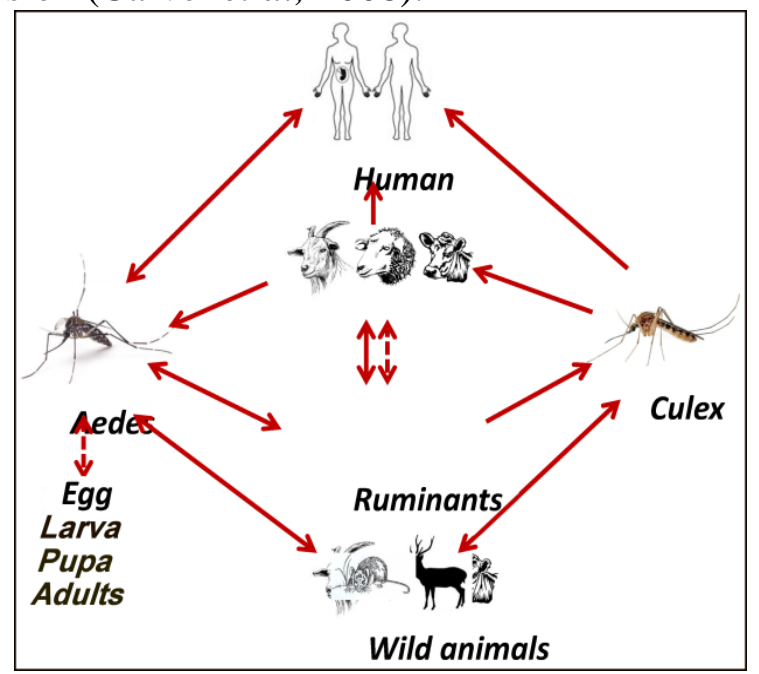

Pathogenesis: Ross River virus (RRV) is an enveloped RNA virus; distinct genetic types have been found in Eastern and Western Australia, with a mix in northern Australia. The membrane bilayer, which surrounds the nucleocapsid, is penetrated by spikes, each of which consists of glycoproteins E1 and E2 (Cheng et al, 1995). E2 is thought to be involved in recognition of the cellular receptor in the host (Smith et al, 1995). Relapse or persistence of symptoms in many patients may be related to persistent replication within synovial macrophages despite neutralizing antibodies and antiviral cytokine responses (Boyd et al, 2001). This process may be initiated by an initial $\mathrm{IgG}$ anti-RRV antibody response, which enhanc- 
es infection in macrophages and monocytes (Linn et al, 1996).

Functional polymorphisms in immune response genes, contribute to individual susceptibility and outcome. Polymorphisms in the IFN-gamma and IL10 loci influence cytokine production and the severity and duration of illness after infection with RRV (Vollmer-Conna et al, 2008). These risk-associated cytokine genotypes may act in combination to potentiate their impact on illness severity. IL10 is a potent inhibitor of IL-1 beta and TNF-alpha production by macrophages, and these cytokines often have synergistic activities in induction of inflammation in the acute sickness response. In vitro models showed that cellular antiviral response can direct selective pressure for viral sequence evolution that impacts on viral fitness and sensitivity to alpha/beta interferon (Lidbury et al, 2011). Arthritis of RRV infection is mediated by local cell-mediated immune responses. In the majority of patients, inflammation is present in the absence of detectable virus, although RRV/DNA was identified in inflamed synovium of some patients more than a month after symptoms onset (Soden et al, 2000).

Rash of RRV infection may be a manifestation of a cell-mediated immune response to viral antigen in the basal epidermal and eccrine duct epithelial cells. Circulating immune complexes have not been found in patients with persistent symptoms (Fraser et al, 1988). In a mouse model, macrophages have been shown to be the primary mediators of muscle damage (Lidbury et al, 2000)

Clinical manifestations: Ross River virus (RRV) infection has been observed in individuals between 4 and 85 years of age; the disease occurs more commonly in women. The incubation period for acute presentations is usually 3 to 9 days, but may be as long as 21 days. The subclinical infection is common (Harley et al, 2001)

Symptomatic RRV presents in one of the three ways: a- Acute febrile illness with arthritis and rash, b- Acute fever, rash, or ar- thritis alone, and c- Chronic polyarthritis or polyarthralgia (Fraser et al, 1983).

There are no specific laboratory tests for RRV-infection. Leukocyte count is usually normal; atypical lymphocytes or a mild neutrophilia may be in some patients, serum Creactive protein concentration usually normal, but modest elevations in the erythrocyte sedimentation rate may be observed.

Arthritis: The most dramatic clinical features of RRV infection are marked arthralgia and myalgia. Joint pains are present in more than $95 \%$ of patients. True arthritis occurs in 40 percent of patients. The joints of the extremities are most frequently involved, especially the wrists, knees, ankles, and the metacarpophalangeal and interphalangeal joints of the fingers. Joint involvement is usually symmetric, but the severity of inflammation may be asymmetric. The intensity of the pain and inflammation may resemble that of gout. Effusions are often present in joints and tendon sheaths, and Achilles tendinitis and plantar fasciitis may occur. Back pain is also common; no association between HLAB27, or another HLA allele has been detected. Synovial fluid analysis early in the disease may suggest viral arthritis. The fluid is viscous with entirely or predominantly mononuclear cells; neutrophils may comprise up to $12 \%$ of cells (Fraser, 1986). Kivity et al. (2011) stated that travel returnees might complain of protracted rheumatic symptoms, but there are sparse data regarding their causes. In a retrospective analysis of Israeli travelers who were referred to the Sheba Medical Center from January 2005 to January 2010 with prolonged (>4 weeks) nontraumatic arthralgia or arthritis. They found that 14 patients ( 7 men \& 7 women) with post-travel arthritis/arthralgia were seen, 5 patients were diagnosed with reactive arthritis, and 9 were diagnosed with rheumatic symptoms related to infection with Alphaviruses: Chikungunya virus or RRV. Some disability remained for several months in most cases, but only one case of reactive arthritis eventually evolved to a chronic spon- 
dyloarthropathy. They concluded that travelrelated arthritis persisted several months after the exposure, and assessing patients' travel history may help in evaluation of some cases with rheumatic manifestations.

Rash and fever: Rash and fever are observed in about one-half of patients with RRV infection. Rash and arthritis usually develop within two days of one another, but may be separated by up to two weeks. The rash may occur before or after the arthritis. It is typically short-lived (1 to 10 days) but may persist for several months. The palms, soles of the feet, face, and mucous membranes of the mouth may be involved. The rash usually consists of 1-5mm maculopapular lesions on the limbs and trunk; it is often sparse, although in some cases it is dense and can include purpuric areas or small vesicles. Fever up to $39^{\circ} \mathrm{C}$, present early in RRV infection in about $20 \%$ and usually dropped within 3 days. Chills and delirium occurred; but rigors unusual (Aaskov et al, 1981).

Other clinical features: Fatigue is the most frequent constitutional symptom, occurring in $90 \%$ of patients. It may be prominent, even in the absence of fever, and may persist after other symptoms resolve (Bennett et al, 1998). Anorexia and headache $(50 \%$ patients) are common. Other symptoms and signs include diarrhea, neck stiffness, photophobia, splenomegaly, aseptic meningitis (Penna and Irving, 1993), hematuria and glomerulonephritis (Anstey et al, 1981), and superficial lymphadenopathy (usually mild; occasionally tender). Several patients with encephalitis have been described (Scrimgeour, 1999), one case of fatal encephalitis was attributed to RRV infection (Scrimgeour et al, 1987). RRV was not associated with congenital abnormalities, although transplacental viral transmission was described (Aaskov et al, 1991).

Clinical course: The average duration of symptoms differs considerably in different reports. Some arthralgias persist for more than three months in two-thirds of patients, but it usually steadily diminishes in severity over that time (Harley et al, 2002). For example, non-steroidal anti-inflammatory drug use decreased from $63 \%$ at one month to $15 \%$ at three months. Early studies suggested patients can have persistent arthralgia, myalgia, and fatigue for more than a year after infection; more recent evidence suggests that symptoms usually resolve within three to six months (Westley-Wise et al, 1996). Many patients with longer duration of symptoms had other underlying comorbidities such as rheumatic disease or depression. But, degenerative joint changes did not occur and relapses were infrequent (Doggett et al, 1999).

In a prospective cohort study of patients with RRV, Epstein Barr virus, or Q fever infection, $12 \%$ of patients had prolonged illness with disabling fatigue, musculoskeletal pains, neurocognitive difficulties, and mood disturbance at six months following initial infection. Out-come was predicted by severity of acute illness rather than the underlying microbiologic diagnosis (Hickie et al, 2006).

Diagnosis: Ross River virus (RRV) infection should be suspected in the setting of acute polyarthritis and rash with a history of travel or residence in endemic or epidemic areas.

Differential diagnosis: Differential diagnosis includes rubella, infectious mononucleosis, parvovirus B19, Henoch-Schönlein purpura (IgA vasculitis), serum sickness, a drug reaction, erythema multiforme, and systemic lupus erythematosus. It also includes other arboviral infections, mainly Barmah Forest virus infection and Chikungunya fever.

Other causes of arthritis and/or arthralgia are Hepatitis A, B \& C, Parvovirus, Rubella and Rubella vaccine, Chikungunya, Diffuse infiltrative lymphocytosis syndrome, Dengue virus, Mumps virus, Coxsackie virus and Echovirus, Adenovirus infection, Herpes virus, Varicella, Epstein-Barr virus, Herpes simplex, Cytomegalovirus, HIV \& HIV-associated arthritis, reactive, septic and psoriatic arthritis and others (Daily et al, 2016).

Barmah Forest virus: Barmah Forest virus 
(BFV) is an alphavirus transmitted by mosquitoes that causes polyarthritis. BFV causes approximately $10 \%$ of epidemic polyarthritis in north-eastern Australia. It was first recognized as a cause of human infection in 1988 and has been increasingly reported in Australia (Lindsay et al, 1995). Epidemics were recognized in the Northern Territory (1992), Western Australia in (1992 to 1993) after (Tong et al, 2001), coastal New South Wales (1995), Victoria (2002) and Queensland (2002 to 2003) after Passmore et al. (2002)

Transmission of BFV is determined by a number of environmental factors. Transmission peak occurs in summer and autumn. Endemic activity is believed to be restricted to northern Australia (Naish et al, 2009). Exotic vector mosquitoes involved in past epidemics include Aedes camptorhynchus (1993), Ae. vigilax (1995) and Ochlerotatus camptorhynchus (2002). High rates of infection among brushtail possums suggested that they may play a role in transmission of urban human infection (Russell, 2002).

The BFV clinical manifestations are similar to those of RRV although, in general, $\mathrm{BFV}$ tends to cause milder disease. Rash is more common with BFV infection, but arthritis is more prominent in RRV infection, although these diseases cannot be distinguished based on symptoms alone. Among BFV 84 patients, the commonest symptoms and signs were lethargy (89\%), joint pain $(82 \%)$, and rash $(68 \%)$. Dermatologic pictures include urticated erythema and widespread vesiculopapular, macular, or purpuric eruptions (Beard et al, 1997). Ross River virus can result in debilitating arthritis and other symptoms (as muscle ache and lethargy), sometimes recurred over many years. How the virus causes these symptoms is still not well understood. Ross River Virus discovery may also have implications to other disease-causing viruses such as HIV, respiratory viruses and the virus that causes dengue fever.

$\mathrm{BFV}$ diagnosis is confirmed by a virus-specific-IgM response (Cashman et al, 2008).

Laboratory evaluation: Diagnosis of RRV infection is generally established by serology; the most common serologic methods are the hemagglutination inhibition (HI) antibody test and the ELISA test. A fourfold rise in HI titer is diagnostic; levels of $\geq 1: 1280$ indicate recent infection. RRV-specific IgM persists for months after acute infection. Thus, acute infection should be confirmed by rising IgM titers if patients live in endemic areas. Testing for a specific $\operatorname{IgA}$ response can demonstrate acute infection in patients with persistent high levels of anti-IgM and IgG antibodies although this test is rarely necessary (Carter et al, 1987).

Viral culture and polymerase chain reaction (PCR) are less widely used diagnostic tools. RRV can be isolated from blood taken early in the course of infection. RRV was not been cultured from joint fluid, but viral antigen was detected by the immunofluorescence in joint fluid specimens collected early in the disease. A nested PCR is being developed for RRV infection, but it remains a research tool currently (Sellner et al, 1994).

Treatment of RRV consists of supportive care; no specific antiviral therapy is available. Treatment of arthralgias and myalgias with analgesics and non-steroidal anti-inflammatory drugs may be helpful. Some may benefit from swimming, hydrotherapy, physiotherapy, or massage; others gain relief only with rest. Basic studies may lead to better therapy in place of current ad hoc approach to treatment.

Prevention: The most important preventive measure is avoidance of mosquito bites. In a case-controlled study, mosquito coils, repellants, and citronella candles were shown to decrease the risk of infection at least twofold; light colored clothing decreased risk threefold (Harley et al, 2005). In contrast, camping increased the risk of Ross River virus (RRV) eightfold. Screens must be fitted to windows and doors in high risk areas. Drainage of mosquito breeding areas in endemic areas may also be helpful over the long-term to control the infection. Mosquito control programs affect RRV disease rates 
(Tomerini et al, 2011) Preemptive surveillance based on knowledge of disease habitats was associated with lower RRV rates.

RRV \& Barmah Forest virus are theoretically transmissible by blood products transfusion; consideration of blood product screening may be warranted. There was no documented transmission of RRV by transfusion; asymptomatic viremia was documented (Dunstan et al, 2008). Theoretical possibility is that transmission may occur with donors from high risk areas, especially at outbreaks time (even if symptomatic patients are excluded from blood donation).

No vaccine is yet available, though experimental vaccines are under investigation (Jones et al, 2010). An inactivated whole virus vaccine that proved effective in mice may a promising candidate for human trials (Holzer et al, 2011).

\section{Conclusion}

Alphaviruses that cause arthritis/arthralgias are globally distributed mosquito-borne RNA viruses causing epidemics of polyarthritis/arthralgia, with disease emerging or reemerging and increasingly being reported in travelers. They are maintained in nature by continuous cycles of transmission between hematophagous arthropods (usually mosquitoes) and enzootic vertebrate hosts (mammals or birds). Bites by infected mosquitoes can result in epizootic infections of humans, with most cases occurring after seasonal rains when mosquito numbers are high.

\section{References}

Aaskov, JG, Mataika, JU, Lawrence, GW, et al, 1981: An epidemic of Ross River virus infection in Fiji, 1979. Am. J. Trop. Med. Hyg. 30: 1053-8.

Aaskov, JG, Nair, K, Lawrence, GW, et al, 1981a: Evidence for transplacental transmission of Ross River virus in humans. Med. J. Aust. 2: 20-6.

Aaskov, JG, Ross, P, Davies, CE, et al, 1981b: Epidemic polyarthritis in northeastern Australia, 1978-1979. Med. J. Aust. 2:17-22.

Amin, J, Hueston, L, Dwyer, DE, Capon, A, 1998: Ross River virus infection in the northwest outskirts of the Sydney basin. Commun. Dis. Intell. 22:101-9.
Anstey, N, Currie, B, Tai, KS, 1991: Ross River virus disease presenting with hematuria. Southeast Asian J. Trop. Med. Publ. Hlth. 22: 281-6.

Beard, JR, Trent, M, Sam, GA, Delpech, VC, 1997: Self-reported morbidity of Barmah Forest virus infection on the north coast of New South Wales. Med. J. Aust.167:525-9.

Bennett, BK, Hickie, IB, Vollmer-Conna, US, et al, 1998: The relationship between fatigue, psychological and immunological variables in acute infectious illness. Aust. N Z J. Psychiatry 32:180-8

Bi, P, Hiller, JE, Cameron, AS, et al, 2009: Climate variability and Ross River virus infections in Riverland, South Australia, 1992-2004. Epidemiol. Infect. 137:1486-92.

Boyd, AM, Hall, RA, Gemmell, RT, Kay, BH, 2001: Experimental infection of Australian brushtail possums, Trichosurus vulpecula (Phalangeridae: Marsupialia), with Ross River and Barmah Forest viruses by use of a natural mosquito vector system. Am. J. Trop. Med. Hyg. 65:77782.

Carter, IW, Fraser, JR, Cloonan, MJ, 1987: Specific IgA antibody response in Ross River virus infection. Immunol. Cell Biol. 65, Pt6:511-8.

Carver, S, Sakalidis V, Weinstein, P, 2008: House mouse abundance and Ross River virus notifications in Victoria, Australia. Int. J. Infect. Dis. 12:528-32.

Carver, S, Spafford, H, Storey, A, Weinstein, P, 2009: Dryland salinity and the ecology of Ross River virus: the ecological underpinnings of the potential for transmission. Vector Borne Zoonotic Dis. 9:611-8.

Cashman, P, Hueston, L, Durrheim, D, et al, 2008: Barmah Forest virus serology; implications for diagnosis and public health action. Commun. Dis. Intell. Q. Rep. 32:263-6.

Cheng, RH, Kuhn, RJ, Olson, NH, et al, 1995: Nucleocapsid and glycoprotein organization in an enveloped virus. Cell 80:621-6.

Daily, JW, Yang, M, Park, S, 2016: Efficacy of turmeric extracts and curcumin for alleviating the symptoms of joint arthritis: A systematic review and meta-analysis of randomized clinical trials. J. Med. Food 19, 8:717-29.

Doggett, SL, Russell, RC, Clancy, J, et al, 1999: Barmah Forest virus epidemic on the south coast of New South Wales, Australia,19941995: viruses, vectors, human cases, and environmental factors. J. Med. Entomol. 36:861-6. 
Dunstan, RA, Seed, CR, Keller, AJ, 2008: Emerging viral threats to the Australian blood supply. Aust. N Z J. Publ. Hlth. 32:354-60.

Fauran, P, Donaldson, M, Harper, J, et al, 1984: Characterization of Ross River viruses isolated from patients with polyarthritis in New Caledonia and Wallis and Futuna Islands. Am. J. Trop. Med. Hyg. 33:1228-32.

Fraser, JR, 1986: Epidemic polyarthritis and Ross River virus disease. Clin. Rheum. Dis. 12: 369-72.

Fraser, JR, Ratnamohan, VM, Dowling, JP, et al, 1983: The exanthem of Ross River virus infection: Histology, location of virus antigen and nature of inflammatory infiltrate. J. Clin. Pathol. 36:1256-60.

Fraser, JR, Cunningham, AL, Mathews, JD, Riglar, A, 1988a: Immune complexes and Ross River virus disease (epidemic polyarthritis). Rheumatol. Int. 8:113-8.

Fraser, JR, Cunningham, AL, Muller, HK, et al, 1988b: Glomerulonephritis in the acute phase of Ross River virus disease (epidemic polyarthritis). Clin. Nephrol. 29:149-53.

Harley, D, Sleigh, A, Ritchie, S, 2001: Ross River virus transmission, infection, and disease: A cross-disciplinary review. Clin. Microbiol. Rev. 14, 4: 909-32.

Harley, D, Bossingham, D, Purdie, DM, et al, 2002: Ross River virus disease in tropical Queensland: Evolution of rheumatic manifestations in an inception cohort followed for six months. Med. J. Aust. 177:352-8.

Harley, D, Ritchie, S, Bain, C, Sleigh, AC, 2005: Risks for Ross River virus disease in tropical Australia. Int. J. Epidemiol. 34:548-54.

Harley, D, Ritchie, S, Phillips, D, van den Hurk, A, 2000: Mosquito isolates of Ross River virus from Cairns, Queensland, Australia. Am. J. Trop. Med. Hyg. 62:561-5.

Hickie, I, Davenport, T, Wakefield, D, et al, 2006: Post-infective and chronic fatigue syndromes precipitated by viral and non-viral pathogens: prospective cohort study. BMJ 333:575-9.

Holzer, GW, Coulibaly, S, Aichinger, G, et al, 2011: Evaluation of an inactivated Ross River virus vaccine in active and passive mouse immunization models and establishment of a correlate of protection. Vaccine 29:4132-8.

Jacups, SP, Whelan, PI, Markey, PG, et al, 2008: Predictive indicators for Ross River virus infection in the Darwin area of tropical northern
Australia, using long-term mosquito trapping data. Trop. Med. Int. Hlth. 13:943-9.

Jardine, A, Speldewinde, P, Lindsay, MD, et $\boldsymbol{a l}, 2008$ : Is there an association between dryland salinity and Ross River virus disease in southwestern Australia? Ecohealth 5:58-62.

Jones, A, Lowry, K, Aaskov, J, et al, 2010: Molecular evolutionary dynamics of Ross River virus and implications for vaccine efficacy. J. Gen. Virol. 91:182-7.

Kay, BH, Boyd, AM, Ryan, PA, Hall, RA, 2007: Mosquito feeding patterns and natural infection of vertebrates with Ross River and Barmah Forest viruses in Brisbane, Australia. Am. J. Trop. Med. Hyg. 76:417-21.

Kelly-Hope, LA, Purdie, DM, Kay, BH, 2004: Differences in climatic factors between Ross River virus disease outbreak and nonoutbreak years. J. Med. Entomol. 41:1116-20.

Kivity, S, Meltzer, E, Bin, H, Schwartz, E, 2011: Protracted rheumatic manifestations in travelers. J. Clin. Rheumatol. 17, 2:55-8.

Lidbury, BA, Rulli, NE, Musso, CM, et al, 2011: Identification and characterization of a ross river virus variant that grows persistently in macrophages, shows altered disease kinetics in a mouse model, and exhibits resistance to type I interferon. J. Virol. 85:5651-6.

Lidbury, BA, Simeonovic, C, Maxwell, GE, et al, 2000: Macrophage-induced muscle pathology results in morbidity and mortality for Ross River virus-infected mice. J. Infect. Dis. 181:2732.

Lindsay, MD, Broom, AK, Wright, AE, et al, 1993: Ross River virus isolations from mosquitoes in arid regions of Western Australia: implication of vertical transmission as a means of persistence of the virus. Am. J. Trop. Med. Hyg. 49:686-90.

Lindsay, MD, Johansen, CA, Smith, DW, et al, 1995: An outbreak of Barmah Forest virus disease in the south-west of Western Australia. Med. J. Aust. 162:291-6.

Lindsay, M, Oliveira, N, Jasinska, E, et al, 1996: An outbreak of Ross River virus disease in Southwestern Australia. Emerg. Infect. Dis. 2:117-22.

Linn, ML, Aaskov, JG, Suhrbier, A, 1996: Antibody-dependent enhancement and persistence in macrophages of an arbovirus associated with arthritis. J. Gen. Virol. 77, Pt 3:407-12. Mackenzie, JS, Smith, DW, 1996: Mosquito- 
borne viruses and epidemic polyarthritis. Med. J. Aust. 164:90-4.

Mylonas, AD, Brown, AM, Carthew, TL, et al, 2002: Natural history of Ross River virusinduced epidemic polyarthritis. Med. J. Aust. 177:356-60.

Naish, S, Hu, W, Nicholls, N, et al, 2009: Socio-environmental predictors of Barmah Forest virus transmission in coastal areas, Queensland, Australia. Trop. Med. Int. Hlth. 14:247-50.

Passmore, J, O'Grady, KA, Moran, R, Wishart, E, 2002: An outbreak of Barmah Forest virus disease in Victoria. Commun. Dis. Intell. Q. Rep. 26:600-4.

Penna, JE, Irving, LG, 1993: Evidence for meningitis in Ross River virus infection. Med. J. Aust. 159:492-8.

Quinn, HE, Gatton, ML, Hall, G, et al, 2005: Analysis of Barmah Forest virus disease activity in Queensland, Australia, 1993-2003: Identification of a large, isolated outbreak of disease. J. Med. Entomol. 42:882-9.

Robertson, GJ, Doggett, S, Seeman, O, et al, 2004: Ross River virus and its vectors in Sorell Municipal Area, south-eastern Tasmania, January to March 2002. Commun. Dis. Intell. Q. Rep. 28:261.

Rosen, L, Gubler, DJ, Bennett, PH, 1981: Epidemic polyarthritis (Ross River) virus infection in the Cook Islands. Am. J. Trop. Med. Hyg. 30: 1294-8.

Russell, RC, 2002: Ross River virus: Ecology and distribution. Ann. Rev. Entomol. 47:1-8.

Scrimgeour, EM, 1999: Suspected Ross River virus encephalitis in Papua New Guinea. Aust. N Z J. Med. 29:559-603.

Scrimgeour, EM, Aaskov, JG, Matz, L, 1987: Ross River virus arthritis in Papua New Guinea. Trans. R. Soc. Trop. Med. Hyg. 81:833-6.

Selden, SM, Cameron, AS, 1996: Changing epidemiology of Ross River virus disease in South Australia. Med. J. Aust. 165:313-8.

Sellner, LN, Coelen, RJ, Mackenzie, JS, 1994: Sensitive detection of Ross River virus--a onetube nested RT-PCR. J. Virol Meth. 49:47-52.

Smith, TJ, Cheng, RH, Olson, NH, et al, 1995: Putative receptor binding sites on alpha-viruses as visualized by cryoelectron microscopy. Proc. Natl. Acad. Sci. USA 92:10648-52.

Soden, M, Vasudevan, H, Roberts, B, et al, 2000: Detection of viral ribonucleic acid and histologic analysis of inflamed synovium in Ro- ss River virus infection. Arthritis Rheum. 43: 365-9.

Suhrbier, A, La Linn, M, 2004: Clinical and pathologic aspects of arthritis due to Ross River virus and other alphaviruses. Curr. Opin. Rheumatol. 16:374-80.

Tesh, RB, McLean, RG, Shroyer, DA, et al, 1981: Ross River virus (Togaviridae: Alphavirus) infection (epidemic polyarthritis) in American Samoa. Trans. R. Soc. Trop. Med. Hyg. 75: 426-30.

Tomerini, DM, Dale, PE, Sipe, N, 2011: Does mosquito control have an effect on mosquitoborne disease? the case of Ross River virus disease and mosquito management in Queensland, Australia. J. Am. Mosq. Control Ass. 27:39-44.

Toivanen, A, 2008: Alphaviruses: An emerging cause of arthritis?. Curr. Opin. Rheumatol. 20: 486-90.

Tong, S, Bi, P, Hayes, J, et al, 2001: Geographic variation of notified Ross River virus infections in Queensland, Australia, 1985-1996. Am. J. Trop. Med. Hyg. 65:171-5.

Tong, S, Hu, W, McMichael, AJ, 2004: Climate variability and Ross River virus transmission in Townsville Region, Australia, 1985-1996. Trop. Med. Int. Hlth. 9:298-102.

Vollmer-Conna, U, Piraino, BF, Cameron, B, et al, 2008: Cytokine polymorphisms have a synergistic effect on severity of the acute sickness response to infection. Clin. Infect. Dis. 47:141822.

Weinstein, P, Judge, D, Carver, S, 2011: Biological and cultural coevolution and emerging infectious disease: Ross River virus in Australia. Med. Hypotheses 76:893-9.

Westley-Wise, VJ, Beard, JR, Sladden, TJ, et al, 1996: Ross River virus infection on the North Coast of New South Wales. Aust. N Z J. Publ. Hlth. 20:87-91.

Williams, CR, Fricker, SR, Kokkinn, MJ, 2009: Environmental and entomological factors deter-mining Ross River virus activity in the River Murray Valley of South Australia. Aust. N Z J. Publ. Hlth. 33:284-90.

Wolstenholme, J, 1992: Ross River virus: an Australian export? Med. J. Aust. 156:515-9.

Woodruff, RE, Guest, CS, Garner, MG, et al, 2006: Early warning of Ross River virus epidemics: combining surveillance data on climate and mosquitoes. Epidemiology 17:569-74. 